\title{
Independent Stage as a Learning Model in Achieving Competency Professionalism Development Program Module in Residency Program of Obstetric and Gynecology Faculty of Medicine Hasanuddin University
}

\author{
Nasrudin Andi Mappaware ${ }^{1,2, *}$, Deviana Soraya Riu ${ }^{1}$, Nugraha U.P ${ }^{1}$, Andi \\ Mardiah Tahir ${ }^{1}$, Elizabet Catherine Jusuf ${ }^{1}$, Arlen ${ }^{3}$
}

${ }^{I}$ Department of Obstetrics and Gynecology, Faculty of Medicine, Hasanuddin University

${ }^{2}$ Department of Obstetrics and Gynecology, Faculty of Medicine, Universitas Muslim Indonesia

${ }^{3}$ Resident of Obstetrics and Gynecology Department, Faculty of Medicine, Hasanuddin University

*Corresponding author email: ernase@yahoo.co.id

\begin{abstract}
Background and Objectives: Competence and professionalism are two main aspects of an Obstetrics and Gynecology (OBGYN) specialist. A continuous learning process, introduction, development, and training are needed, both through classroom learning sessions and practice in real situations so that learning objectives can be achieved within the OBGYNs' Doctor Education Collegium allotted time.

Method: Literature research and observation of OBGYN residents learning activities in the professional development module with independent stage activities as a learning model were conducted.

Result: The standard collegiate professionalism development module is prepared as a learning reference for assessing professional competence achievement. In this module learning activity, OBGYN residents carry out an independent stage in a regional education network hospital for 2 to 3 months with various activities, both in education and health services aspects. Learning objectives to achieve competence: 1) Communicating and Providing Counseling, 2) Teamwork and Leadership, 3) Administration and Service Management, 4) Negotiating and Motivating Others, 5) Carrying Out Clinical Training, and 6) Doing good medical practice and professional accountability.

Conclusion and Recommendation: The independent activity stage of OBGYN residents increased professional competence achievement. The independent stage becomes a learning model for achieving the competency of the professional development module.
\end{abstract}

Keywords: Independent stage, Professionalism development module, OBGYN residents competence.

\section{INTRODUCTION}

Medicine is a profession that requires comprehensive understanding of a large amount of clinical knowledge and skills, including high standards of appropriate habits and behavior. The medical and health professionals agreed on contracts of professionalism. However, most of the components of professionalism are unwritten agreements. Professional behavior is a part of competence that must be mastered by a physician. Therefore, it is highly appropriate to begin the learning process early [1].

Professionalism in medicine consisted from several components of behavior, including: altruism, competence, honesty and integrity, performance, management, and respect for others and humanism [1].

Professionalism in medicine can be obtained through the internalization of values and responsibilities to patients, which processes begins when these professionals first enter medical school [1].

The medical doctor is a profession whose jobs and activities require them to interact directly with humans. Professional medical doctors are required to recognize and know all things related to humans, both humans as individuals and humans as social beings.

Thus, a prospective medical doctor and medical 
doctor needs to understand all aspects required to deal with a human being, since their conception to old age and even to the end of their life [2].

Competent and professional are the two main aspects that must be owned by an Obstetrist and Gynecologyst (OBGYN). To support these two aspects, a continuous learning process, introduction, development and training in medical practice, especially in the field of obstetrics-gynecology is needed, both through classroom learning sessions (theoretical approach) and practice in real situations (independent stage) with strong adherence to medical ethics, professional standards, scientific principles and applications of clinico-medical practices to achieve comprehension to learning objectives within the allocated time in learning modules designed by the College of Obstetrics and Gynecology.

\section{METHOD}

This study was conducted through literature search and observation of learning activities of OBGYN resident medical doctors in the module 19: professionalism development with independent stage activity approach as a learning model.

In the national Obstetrics and Gynecology specialist education program which refers to the guide from the module designed by Indonesian College of Obstetrics and Gynecology which consists of 3 main modules, which are the Obstetrics Module, Gynecological Modules and Supporting Modules. Module 19: professionalism development is a part of the Supporting Modules that are presented from the first semester (debriefing) to the final semester (eighth semester). To facilitate comprehension of competencies in this module, after the debriefing session, each resident in independent stage is given mandatory assignments to carry out at the Faculty of Medicine, University of Hasanuddin educational network hospital in several areas, both in Sulawesi and outside Sulawesi. In this independent stage, in addition to carrying out medical service and educational tasks, the core idea which is also the main focus is to facilitate residents to train and develop themselves in aspects of professionalism.

\section{RESULTS AND DISCUSSION}

The supporting module, in this case the module 19: professionalism development, is a standard design by the College of Obstetrics and Gynecologist prepared as a learning framework to assess comprehension of professionalism. Medical professionalism is an important part of the competences that need to be mastered by a specialist in Obstetrics and Gynecologist (OBGYN).
Referring to the vision of the Faculty of Medicine of University of Hasanuddin, which aim to produce humanist graduates who are able to serve the community by developing a reputable (digital) education system with a slogan "From Digital to Humanism", the vision of Department of Obstetrics and Gynecologist of Faculty of Medicine of University of Hasanuddin is to produce humanist graduates with scientific literacy, and to actualize one of its missions, which is to provide continuous education and training with applications of innovative technology and internalize humanistic values, norms, and academic ethics Therefore, a strategy and innovation in the education curriculum is needed, especially by implementing the development of medical professionalism included in the module for residents in order to strengthen professionalism, which in turn may provide a solution to overcome the challenges to improve the competence of OBGYN specialist in Indonesia [3].

Education about medical professionalism for OBGYN residents who may encounter a wide variety clinical problems which may happen in Indonesia is an urgent task. Learning about medical professionalism can help residents to reach individual maturity, increase ethical awareness, be able to navigate in the domain of moral, which in turn will produce humanist and professional OBGYN specialist to provide health services.

In this module, the activity of the residents in independent stage focuses on skills in case managements with more comprehensive and holistic approace, including teamwork, service and training management, problem identification, continued with thorough planning and delivering activies to solve these problems, training each student in building trust, effective communication, and good relationship between patient and doctor as well as training oneself from interprofessional education to interprofessional collaboration. Reports for activities and cases encountered during the independent stage are analyzed in accordance with the professionalism development module by peerstudents. In addition to discussion, students also hone skills in accordance with the objectives, namely training medical skills and as an introduction to various problems that students may encounter in the future, especially in establishing trust, communication, and good relationships between patients and doctors and skilled in performing and incorporating Basic Principles of Bioethics into problems and clinical ethical decisions as well as health humanities problems, to prepare them before serving tge society and having a clear responsibilty as a professional OBGYN specilalist.

This module of professionalism development is presented to OBGYN residents starting from the early semester to the final semester (first to eighth semester). Objectives of Module 19: 
professionalism development in the field of obstetrics and gynecology: This module is designed for the learning process for introduction, development and accomplishment of professional competence in the practice and implementation of medical activities, especially in the field of Obstetrics-Gynecology, through in-class learning sessions and practice in real situations based on ethics, professional standards, scientific principles and clinico-medical applications [3].

Upon completion of the learning modules and competencies are mastered, learners are expected to be able to [3]:

\section{A. Conduct Communication And Counseling,} specific skills:

a. Able to communicate effectively through verbal and written communication with patients, families and communities

b. Able to deliver bad news wisely

c. Able to communicate effectively through verbal and written communication with colleagues and other health professionals

d. Able to provide counseling to patients, families and colleagues

B. Teamwork and Leadership, specific skills:

a. Able to work effectively in a team

b. Able to demonstrate leadership skills

c. Able to collaborate with professional from other field

C. Administration and Service Management, specific skills:

a. Able to master and function according to organizational structures in local and national level

b. Able to innovate and modifying the organizational structures to be more effective

c. Able to work in fields related to specific skills or administration

D. Negotiating and Motivating Others, skills:

a. Able to carry out the principles of effective negotiation

b. Able to respond appropriately in formal and informal situations

c. Able to provide advocacy to other parties

E. Conducting Clinical Training, specific skills:

a. Able to apply the principles of clinical training

b. Able and responsible for providing guidance, education and training on reproductive health to junior residents or other health workers

F. Doing good medical practice (good medical practice) and professional accountability , specific skills:

a. Able to conduct self -development and sustainable professionalism

b. Able to form lifelong study habits from various learning sources

6.3 Able to act professionally in all time

6.4 Able to prioritize work including personal health, workload management and time management in effective manner

Professionalism stems from the root word "profession". According to The Great Indonesian Dictionary/Kamus Besar Bahasa Indonesia/ (2008), professionalism is "the behavior that is the characteristic of a profession" . Each profession has their own power and therefore has special responsibilities. Each profession have specialized skills and are united by the same educational background, and persons who join professional groups have special knowledge and skill which the majority of people do not have. Members of a certain profession declare a commitment regarding their ability, integrity and morals, altruism, and support for the welfare of society. Members of this profession are governed by a code of ethics [4].

Professional behavior are behavior based on knowledge and skills that reflect the values of professionalism. The values of professionalism can be seen from the manner of speaking, human interactions, and daily apperance [4].

Aspects of professionalism consist of [5]:

a. Potential aspect, namely having dynamic hereditary potential which continues to develop and can be developed. These potentials consisted of memory, intellectual capabilities, talents and interests, motivation.

b. Professional or vocational aspects, namely having the ability and skills or honesty in certain fields with abilities and skills that can devote themselves to work and obtain optimal results.

c. Functional aspects, namely carrying out their work appropriately by working according to their duties.

d. Operational aspects, namely utilizing abilities and skills in the processes and procedures for carrying out work activities that each professional engaged in.

e. Productivity aspects, namely having a motive in accomplishment, pursuit of success and delivering good results both in quantity and quality.

The characteristics and attributes of professionalism include :

a. Professionalism requires the nature of pursuing the perfection of results, therefore professionals required to always seek quality improvement.

b. Professionalism requires sincerity and thoroughness of work which can only be obtained through experience and habit. 
c. Professionalism demands persistence and fortitude, that is, not being easily satisfied or giving up until results are achieved.

d. Professionalism requires high integrity that is not deterred by "compulsion" or faith such as wealth and enjoyment of life .

e. Professionalism requires unanimity of thought and action to maintain high work effectiveness.

Professionalism is a person's attitude towards his job, which is assessed through five dimensions, namely [6]:

a. Devotion to the profession. Professionalism is a paradigm which will be reflected by the dedication of a person in using their knowledge and skills. This attitude is related to the individual's determination in keep doing the job even though the intrinsic reward is reduced. Attitude in this dimension view work as a person's total self-expression.

b. Social obligation. This dimension describes the benefits obtained, both by the community in the presence of a job and for the professionals themselves.

c. Independence. This dimension declares that professionals must be able to make their own decisions without pressure from other parties. A sense of independence comes from the freedom to do what is best according to the professional's view in the particular situation.

d. Trust in the profession. The trust that the most competent persion to assess professional performance are not those who do not have competencies in the field of knowledge and work.

e. Relationships with fellow professions. Professionalism requires professional ties in both formal organizations and informal peer groups as the main source of professional ideas. Through this professional connection, professionals build awareness of their profession.

Activities in the independent stage which are carried out by residents for two months are expected to be able to train and develop the objectives of the module of professionalism development as stated in the previous objectives, the learning objectives are a combination of: 1) cognitive aspects (theory of communication, motivation and information delivery) and psychomotor aspects or skills to implement and gain benefits from effective communication, positive or constructive motivation and ways of delivering specific information, 2) cognitive aspects (teamwork, leadership, collaboration with other related professions/fields of science) which will support the aspects psychomotor or skills to implement and benefit from cooperation within/between groups and leadership initiatives, 3) cognitive aspects (systems and structures of national and regional health organizations, carrying out and monitoring the main tasks and functions of individuals or groups within an organization) which are important support of psychomotor aspects or skills to carry out and benefit from the implementation of tasks and responsibilities in accordance with their position in the organizational structure, improving individual and institutional performance and carrying out organizational missions and strategies, 4) cognitive aspects (principles, characteristics, stages and techniques of effective negotiation and various approaches in motivation) which will support the psychomotor aspects or skills to implement and benefit from problem solving efforts, negotiate, motivate and advocate the interests of individuals, groups, collegials and programs, 5) cognitive aspects (principles and approaches in training, planning and implementing and evaluating clinical training based on competence) which as a basis for the psychomotor aspects or skills to implement and benefit from implementing a positive atmosphere in training, using training devices, delivering interactive presentations, effective demonstrations and constructive guidance, conducting clinical training and training evaluation, including skill to apply all these principles, knowledge and skills to the education of OBGYN residents or other health professionals, 6) cognitive aspects (standards or best practice in the field of medicine, principles of doctor-patient relations, rights and obligations clients, the interests of personal health) which as a basis for the psychomotor aspects or skills to implement and benefit from maintaining and improving performance/competence, measuring the level of personal capability and acknowledging collegial proficiency, and ensuring public accountability for individual and professional professionalism, where the learning process and the professionalism development skills using several methods including illustrative lectures, brainstorming and discussion, case studies, bed-side teaching, demonstrations, practice, guidance and performance demonstration assessments. Implementation of the plan and learning activities in independent stage conducted at the regional hospital are performed in real life situations. The stage of simulative competency-acquisition requires a series of guidance and independent practice to achieve the desired skill level within a certain time allocation (during the stage) [3].

Implementation and assessment of the situation during independent stage of module 19: the professionalism development in the field of obstetrics and gynecology for OBGYN residents can improve the ability to communicate and provide counseling, teamwork and leadership, administration and management of services, 
negotiating and motivating others, implement clinical training, and performing good medical practice and professional accountability, this can be evaluated in the resident's logbook from the first semester to the eighth semester of education as OBGYN resident.

\section{CONCLUSION}

Based on the results and discussion that has been previously presented, it can be concluded that the independent stage activities of OBGYN residents in Faculty of Medicine, University of Hasanyddin can improve the acquisition of professional competence. The independent stage becomes a learning model for achieving the competencies based from the module of professionalism development.

\section{AUTHORS' CONTRIBUTIONS}

All authors contributed to study planning, and data collection and interpretation, and reviewed and approved the final version of this manuscript.

\section{ACKNOWLEDGMENTS}

Authors would like to express grattitude to the entire team of the Specialist Medical Education Program for Obstetrics and Gynecology of Faculty of Medicine, University of Hasanuddin who have contributed in during this study.

\section{REFERENCES}

[1] Purnamasari CB, Claramita Mora,

Prabandari YS, Jurnal Pendidikan

Kedokteran Indonesia $\quad$ Vol.4 No.1

Maret,2015

[2] Nadeak Bernadetha, Jurnal Etika

Pendidikan: Keteladanan Dalam

Profesionalisme Vol.8 No.2 Juli,

2015:123-129

[3] Modul penunjang Kolegium Obstetri dan

Ginekologi Indonesia, Modul 19.

Pengembangan Profesionalisme dalam

Obstetri dan Ginekologi

[4] Kresna DB, Analisis Profesionalisme dr.

Novi Damayanti di Puskesmas Gombong I;

Universitas Sebelas Maret, Surakarta, 2012

[5] Hamalik, Oemar. Psikologi Belajar dan

Mengajar. Bandung: Sinar Baru Al

Gesindo. 2000

[6] Jatman, Darmanto. Psikologi

Perkembangan. Cetakan Pertama.

Semarang: Badan Penerbit Universitas

Diponegoro. 2000 